\title{
PM2.5 induces cell cycle arrest through regulating mTOR/P70S6K1 signaling pathway
}

\author{
YU ZHANG $^{1}$, DAN YANG $^{1,2}$, BIAO YANG $^{1}$, BINGYU LI $^{1}$, JIE GUO $^{1}$ and CHUNLING XIAO ${ }^{1}$ \\ ${ }^{1}$ Key Lab of Environmental Pollution and Microecology of Liaoning Province, and ${ }^{2}$ Department of Pharmacology, \\ Shenyang Medical College, Shenyang, Liaoning 110034, P.R. China
}

Received June 11, 2018; Accepted February 4, 2019

DOI: $10.3892 /$ etm.2019.7466

\begin{abstract}
Fine particulate matter (PM2.5) pollution has become a serious problem in China. This study aims to elucidate the toxicity mechanism of PM2.5. Protein levels were detected by western blotting and RT-qPCR, and cell cycle was detected by flow cytometry. The results showed that exposure to PM2.5 induces cell cycle arrest and downregulation of the expression of cyclin D1 protein. Moreover, the protein expression of thymidylate synthase (TS) enzyme was found to be downregulated and the mRNA expression of TS was upregulated after PM2.5 exposure. Knockout of TS gene promoted cell cycle arrest and downregulation of the expression of cyclin D1 protein after PM2.5 exposure. Our data further revealed that $\mathrm{PM} 2.5$ exposure downregulates the expression of TS and cyclin D1 partially through the downregulation of the mammalian target of rapamycin (mTOR)/P70S6K1 signaling pathway. Thus, these findings indicate that PM2.5-induced cell cycle arrest might be due to the downregulation of mTOR/P70S6K1 signaling pathway, and thus inhibits the expression of TS protein.
\end{abstract}

\section{Introduction}

Air pollution has become one of the tremendous problems of developing cities in China. Less than $13 \%$ of China's cities meet the national ambient air quality standards (1). Air pollution has been listed as one of the environmental risk factors that pose a threat to human health. WHO estimates that air pollution causes 37,000 premature deaths/year, mainly related to fine particulate matter (PM2.5) exposure (2).

The frequent occurrence of foggy haze is due to the excessive production of suspended particles in the atmosphere: PM2.5

Correspondence to: Dr Chunling Xiao, Key Lab of Environmental Pollution and Microecology of Liaoning Province, Shenyang Medical College, 146 Huanghe North Avenue, Shenyang, Liaoning 110034, P.R. China

E-mail: xiaochunling2000@163.com; xiaochunling@symc.edu.cn

Key words: PM2.5, cell cycle arrest, thymidylate synthase protein, cyclin D1 protein, mTOR/P70S6K1 signaling pathway of diameter $<2.5 \mu \mathrm{m}$, containing polycyclic aromatic hydrocarbons, inorganic substances, especially transition metals, and acidic oxides $(3,4)$. The smaller the particle size, the more severe the damage. PM2.5 levels affect health more than large particulate matter because PM2.5 can penetrate into the lungs, alveoli and lung sacs and can be dissolved into the bloodstream (5). PM2.5 has strong toxicity to cardiovascular and cerebral vascular (6), lung cancer $(7,8)$ and nervous system (9). Duan et al established a PM2.5 exposure model for zebrafish and found that PM2.5 predominantly affects organs and causes multiple organ toxicological injuries, including cardiovascular injuries, hepatotoxicity and neurotoxicity (10).

Thymidylate synthase (TS) is a key rate-limiting enzyme in the folate metabolism which catalyzes the conversion of deoxyuridine monophosphate (dUMP) to deoxythymidine monophosphate (dTMP). This conversion essentially influences DNA repair, methylation and synthesis through the production of nucleotides (11). It also functions by catalyzing the methylation of deoxyuridylate to deoxythymidylate with a cofactor 5,10-methylenetetrahydrofolate (methylene THF). This function is essential for the dTMP (thymidine-5-prime monophosphate) pool. It affects DNA replication and repair and thus has been considered to be a target for cancer chemotherapeutic agents, such as 5-fluorouracil, 5-fluoro-2-prime-deoxyuridine and some folate analogs $(3,4)$.

Mammalian target of rapamycin (mTOR) is an evolutionarily conserved serine, threonine protein kinase discovered in recent years and is also an important signal transduction molecule that can be integrated to energy, hormones, amino acids, cellular oxidative stress and other signals. mTOR signaling pathway is involved in many biological processes, such as cell growth, proliferation, apoptosis and autophagy $(12,13)$. P70S6K1 acts as a downstream substrate of mTOR protein. p-mTOR is activated, which regulates the activation of P70S6K1 in cells, thereby controlling cell growth from G1 to $\mathrm{S}$ phase $(14,15)$.

This study found that PM2.5-induced cell cycle arrest might be due to the downregulation of mTOR/P70S6K1 signaling pathway, and thus inhibits the expression of TS protein.

\section{Materials and methods}

Collection and preparation of PM2.5. Sampling sites comprised the streets of Shenyang and samples were collected over 
$48 \mathrm{~h}$. Filters were cut into $2 \mathrm{~cm} \times 2 \mathrm{~cm}$ size and placed into beakers containing a certain amount of saline. Ultrasonic shock was performed 3 times, $10 \mathrm{~min}$ each. The filtrates were centrifuged at $1,000 \mathrm{xg}, 4^{\circ} \mathrm{C}$, for $5 \mathrm{~min}$ and the supernatants were discarded to collect the underlying particles. Then, the particles were freeze-dried in vacuum and preserved at $-80^{\circ} \mathrm{C}(16-18)$. Ma et al have carried out a composition analysis and have revealed that toxic heavy metals and polycyclic aromatic hydrocarbon substances are the main elements of PM2.5 (19).

Animal model. Forty SPF Wistar rats, aged 6-8 weeks with a body weight of $150 \pm 10 \mathrm{~g}$, were selected. All rats were males, purchased from Beijing Weitong Lihua Experimental Animal Technology Co., Ltd. [production license no. SCXK (Beijing) 2012-0001; Beijing, China]. The rats were housed at a temperature of $20-22^{\circ} \mathrm{C}$, relative humidity of $50-60 \%$, and $12 / 12 \mathrm{~h}$ light/dark cycle. During the experiment, the rats were allowed to eat and drink water freely. The rats were randomly divided into 4 groups: PM2.5 exposure group and saline control group, at 2 weeks and 4 weeks, respectively, with 10 rats in each group. Using a mouth-nose exposure system (Beijing Huironghe Technology Co., Ltd., Beijing, China), the experimental group animals were exposed to concentrated PM2.5 at 10 ambient concentrations of $750 \mu \mathrm{g} / \mathrm{cm}^{3}$ for $4 \mathrm{~h} /$ day, 5 days/week for a total of 4 weeks, and the control group animals were treated with physiological saline under similar conditions. The study was approved by the Ethics Committee of Shenyang Medical College (Shenyang, China).

Cell culture and PM2.5 treatment. $\mathrm{H} 1299$ and $\mathrm{H} 292$ cells, obtained from the American Type Culture Collection (cat. nos. CRL-5803 and CRL-1848; ATCC, Manassas, VA, USA), were seeded in RPMI-1640 medium (10\% fetal bovine serum, penicillin, streptomycin $100 \mathrm{kU} / \mathrm{l}$ ) and subcultured at $37^{\circ} \mathrm{C}$, $5 \% \mathrm{CO}_{2}$ at 3 days fluid was changed and passaged once, using $0.25 \%$ trypsin-EDTA digestion. After 2-3 passages, the cells in logarithmic growth phase were equally divided into 4 groups and inoculated into complete RPMI-1640 medium. After $24 \mathrm{~h}$, the cells were treated with different concentrations of PM2.5 suspension (0, 50, 100 and $200 \mu \mathrm{g} / \mathrm{ml})$ for $48 \mathrm{~h}$. Cells were defined as PM2.5 suspension-treated groups and control group, with an equal amount of complete RPMI-1640 medium.

Western blotting. Total protein was extracted with Total Protein Extraction kit (Nanjing Kaiji Biotechnology Development Co., Ltd., Nanjing, China) from the lung tissues of rats and the H1299 and $\mathrm{H} 292$ cells, and the protein concentration was determined by the BCA method. A total of $20 \mu \mathrm{g}$ protein/lane were separated via $8 \%$ SDS-PAGE and were subsequently transferred onto a PVDF transfer membrane and blocked with $10 \%$ fetal bovine serum (Thermo Fisher Scientific, Inc., Waltham, MA, USA) at $20^{\circ} \mathrm{C}$ for $1 \mathrm{~h}$. The membranes were incubated with a primary rabbit anti-human thymidylate synthase, cyclin D1, p-mTOR, p70, $\beta$-actin monoclonal antibodies (dilution, 1:1,000; cat. nos. 5449, 2978, 5536, 2708, and 8457 ) overnight at $4^{\circ} \mathrm{C}$. Then, the membranes were incubated with secondary goat anti-rabbit IgG polyclonal antibody (dilution, 1:1,000; cat. no. 7074) at room temperature for $1 \mathrm{~h}$. Both primary and secondary antibodies were purchased from Cell
Table I. Primer sequences of qPCR.

\begin{tabular}{lc}
\hline Gene & \multicolumn{1}{c}{ Primer sequence } \\
\hline Human-TYMS & U: 5'-TTG AGG AAT TTT GCA TCA ATG-3' \\
& D: 5'-CCA AAA AGA GTC CAG GAC CA-3' \\
Human-GAPDH & U: 5'-TCT CTT AGA TTT GGT CGT ATT-3' \\
& D: 5'-CAT ATT GGA ACA TGT AAA CCT-3' \\
Rat-TYMS & U: 5'-GTG GAT GAA GTA GCC GTG GT-3' \\
Rat-GAPDH & D: 5'-GGC CAT TTT ACC AAA AGC AA-3' \\
& U: 5'-GAC ATG CCG CCT GGA GAA AC-3' \\
& D: 5'-AGC CCA GGA TGC CCT TTA GT-3'
\end{tabular}

U, upstream; D, downstream.

Signaling Technology, Inc. (Danvers, MA, USA). ECL chemiluminescence (SuperSignal Western Pico Chemiluminescent Substrate; Pierce Biotechnology, Inc.; Thermo Fisher Scientific, Inc., Dallas, TX, USA) was used to determine the changes in the expression of various factors in the cell lysates. ImageJ software (version 1.48u; National Institutes of Health, Bethesda, MD, USA) was used for densitometry.

RT-qPCR analysis. TRIzol reagent (Invitrogen; Thermo Fisher Scientific, Inc., Carlsbad, CA, USA) was used to extract total RNA of lung tissue and H1299 and H292 cells. RT kit was purchased from Qiagen GmbH (Hilden, Germany). After the synthesis of the first strand cDNA, qPCR was performed using SYBR-Green and GAPDH as the internal control. The reaction system $(20 \mu \mathrm{l})$ contained $10 \mu \mathrm{l}$ of $1 \mathrm{X}$ SYBR-Green Supermix reagent (Promega Corp., Madison, WI, USA), $0.8 \mu 1$ of upper and lower primers (Sangon Biotech Co., Ltd., Shanghai, China), $2 \mu \mathrm{l}$ of cDNA (10 ng), and $6.4 \mu \mathrm{l}$ of $\mathrm{ddH}_{2} \mathrm{O}$. qPCR amplification parameters were: annealing at $25^{\circ} \mathrm{C}$ for $5 \mathrm{~min}$, extension at $42^{\circ} \mathrm{C}$ for $60 \mathrm{~min}$; inactivation at $70^{\circ} \mathrm{C}$ for $15 \mathrm{~min}$, after extension of the detection of fluorescence signals, a total of 40 cycles. Three replicate wells were set up for each sample, and the relative expression of mRNA was calculated according to the $2^{-\Delta \Delta \mathrm{Cq}}$ method (20). Primer sequences are shown in Table I.

Transient transfection. Cells were seeded into 6-well plates without the addition of antibiotics. After $24 \mathrm{~h}$, the cells were transfected with siRNA inhibitor (Shanghai GenePharma Co., Ltd., Shanghai, China). Approximately $800 \mu 1$ of $150 \mathrm{mM}$ sterilized $\mathrm{NaCl}$ solution were diluted and mixed and placed on the bench for $5 \mathrm{~min}$. Lipofectamine transfection reagent $(\sim 50 \mu \mathrm{l}$; Shanghai GenePharma Co., Ltd.) was added to the $5 \mu \mathrm{g}$ DNA dilution solution. The final volume of the transfection solution was $1 \mathrm{ml}$ and was let to stand for $20 \mathrm{~min}$. The transfection solution was added dropwise to the cell culture medium. After 48-72 h of transfection, gene expression was detected (21).

Flow cytometry analysis. Cells were treated with PM2.5 suspension for $48 \mathrm{~h}$, centrifuged at 13,000 $\mathrm{xg}$ for $3 \mathrm{~min}$ at $4^{\circ} \mathrm{C}$ and washed twice with PBS. Cells were resuspended with PBS, and 2 volumes of $5 \mathrm{ml}$ ethanol were slowly added and mixed, stationary set was at $4^{\circ} \mathrm{C}$. The cells were washed twice 


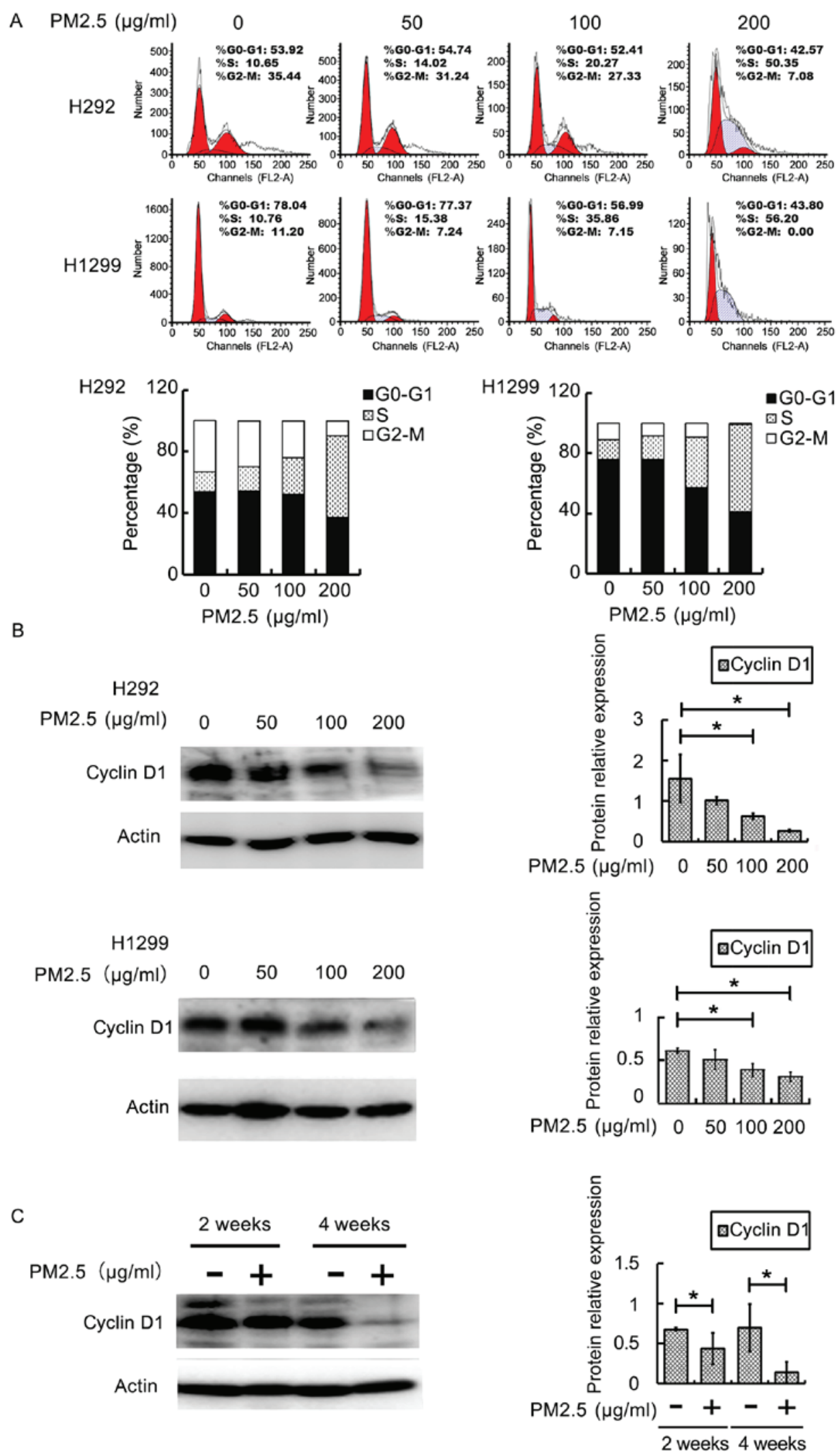

Figure 1. Exposure to PM2.5 induces downregulation of cyclin D1 expression in lung tissue, H1299 and H292 cells, and cycle arrest of lung cancer cells at the S phase. (A) Flow cytometry analysis of H1299 and H292 cell cycles. Western blotting of the expression levels of cyclin D1 protein in (B) H1299 and H292 cells, and $(\mathrm{C})$ rat lung tissue. The final results are summarized in the bar graphs and data are expressed as mean \pm standard deviation $\left({ }^{*} \mathrm{P}<0.05\right)$.

with PBS, resuspended in $1 \mathrm{ml}$ of PI solution and incubated at room temperature for $30 \mathrm{~min}$. The cell cycle was detected by flow cytometry (Muse ${ }^{\mathrm{TM}}$ flow cytometer; Merck Millipore,
Burlington, MA, USA) and the data were analyzed with ModFit 2.0 software (Verity Software House, Inc., Berlin, Germany). 
A

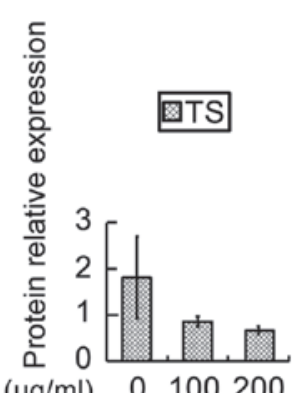

PM2.5 $(\mu \mathrm{g} / \mathrm{ml}) \quad 0 \quad 100200$

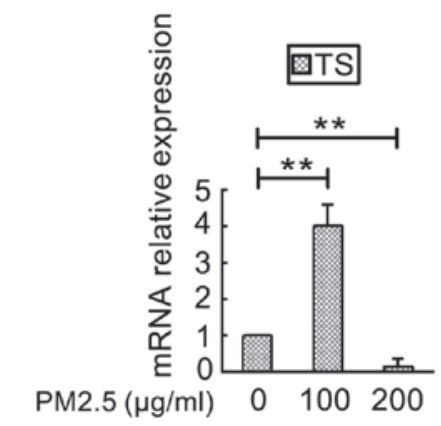

H1299

PM2.5 $(\mu \mathrm{g} / \mathrm{ml}) \quad 0 \quad 100200$

TS

Actin

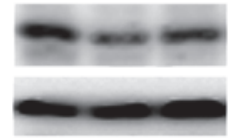

B

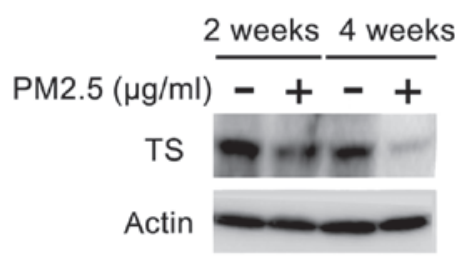

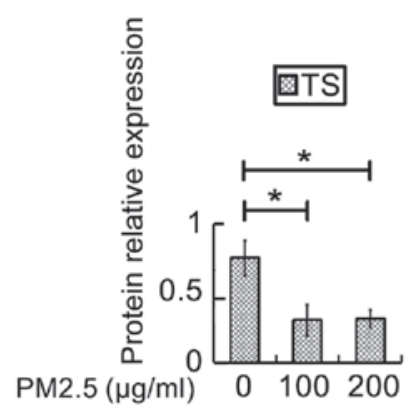

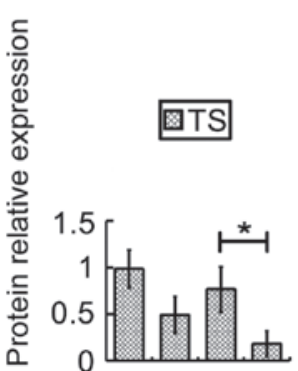

PM2.5 $(\mu \mathrm{g} / \mathrm{ml})$

2 weeks $\overline{4 \text { weeks }}$
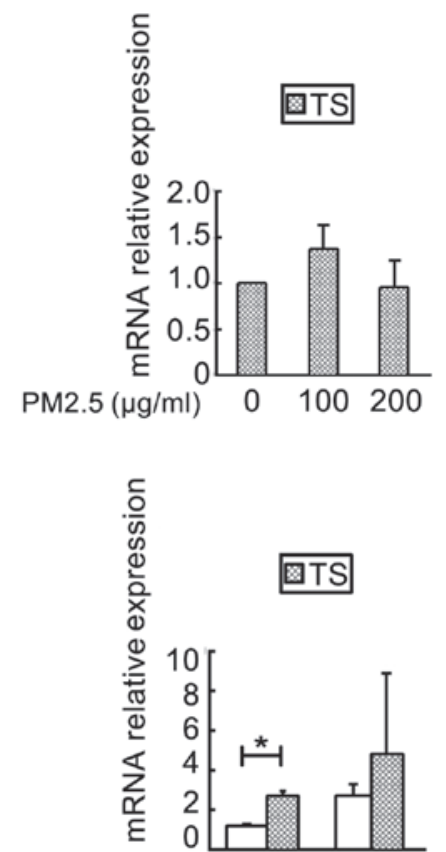

$\mathrm{PM} 2.5(\mu \mathrm{g} / \mathrm{ml})-+\quad++$

$2 \overline{\text { weeks }} \overline{4 \text { weeks }}$

Figure 2. The expression of TS enzyme in lung cancer cells is downregulated by PM2.5 exposure. Western blotting and RT-qPCR analysis of the expression levels of TS protein and mRNA in (A) H1299 and H292 cells, and (B) rat lung tissue. The final results are summarized in the bar graphs and data are expressed as mean \pm standard deviation $\left({ }^{*} \mathrm{P}<0.05,{ }^{* *} \mathrm{P}<0.01\right)$. TS, thymidylate synthase.

Statistical analysis. SPSS 22.0 (IBM Corp., Armonk, NY, USA) was used for the statistical analysis. Results are presented as the mean \pm standard deviation from three independent experiments. Statistical significance was determined with the unpaired Student's t-test and ANOVA. Dunnett's test was the post hoc test used. $\mathrm{P}<0.05$ was considered to indicate a statistically significant difference.

\section{Results}

Exposure to PM2.5 induces cell cycle arrest and downregulation of the expression of cyclin D1 protein. $\mathrm{H} 292$ and H1299 cells were exposed to PM2.5 for $48 \mathrm{~h}$. The results showed that with the increase of PM2.5 concentration, the cell cycles of H292 and H1299 cells were mostly blocked at the S phase. When the concentration of PM2.5 was $200 \mu \mathrm{g} / \mathrm{ml}$, the percentage of H292 and H1299 cells in S phase reached 50.35 and $56.20 \%$, respectively (Fig. 1A). Also, with the increase of PM2.5 concentration, the expression of cyclin D1 at 100 and $200 \mu \mathrm{g} / \mathrm{ml} \mathrm{PM} 2.5$ was downregulated, compared with the control group $(\mathrm{P}<0.05)$ (Fig. 1B).
To analyze PM2.5-induced lung toxicity after injury, an in vivo exposure method was used. It was found that cyclin D1 protein was significantly downregulated $(\mathrm{P}<0.05)$ as the exposure time increased at 2 and 4 weeks, compared with the control group, as seen in Fig. 1C.

Conclusively, our obtained data showed that exposure to PM2.5 for a few weeks can lead to the downregulation of the expression of cyclin D1 protein.

The protein expression of TS enzyme is downregulated and the mRNA expression of TS is upregulated after PM2.5 exposure. As the cell cycle was arrested and the expression of cyclin D1 was downregulated, we hypothesized that DNA synthesis was inhibited after PM2.5 exposure. Therefore, we studied the effect of PM2.5 exposure on the protein and mRNA expression of TS, a key enzyme in DNA synthesis. With the increase of PM2.5 concentration, the expression of TS protein in H1299 cells was downregulated $(\mathrm{P}<0.05)$, the expression of mRNA in $\mathrm{H} 292$ cells was more upregulated $(\mathrm{P}<0.01)$ at $100 \mu \mathrm{g} / \mathrm{ml} \mathrm{PM} 2.5$, and the expression of mRNA in H1299 cells was increased or expressed similarly (P>0.05) at 100 and $200 \mu \mathrm{g} / \mathrm{ml} \mathrm{PM} 2.5$, 
A

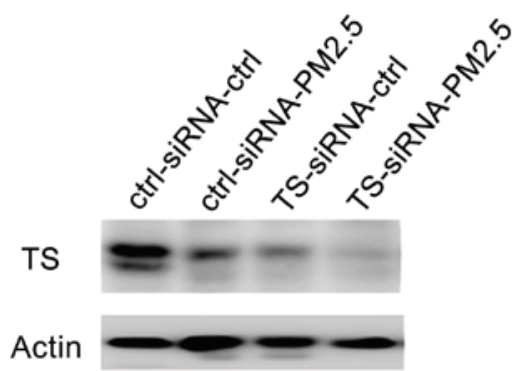

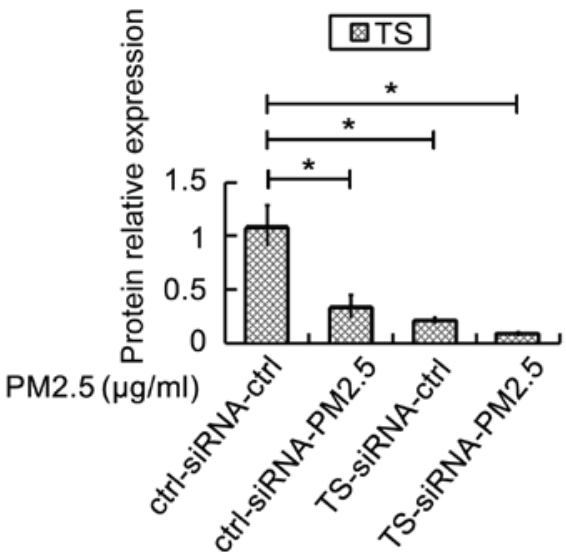

B
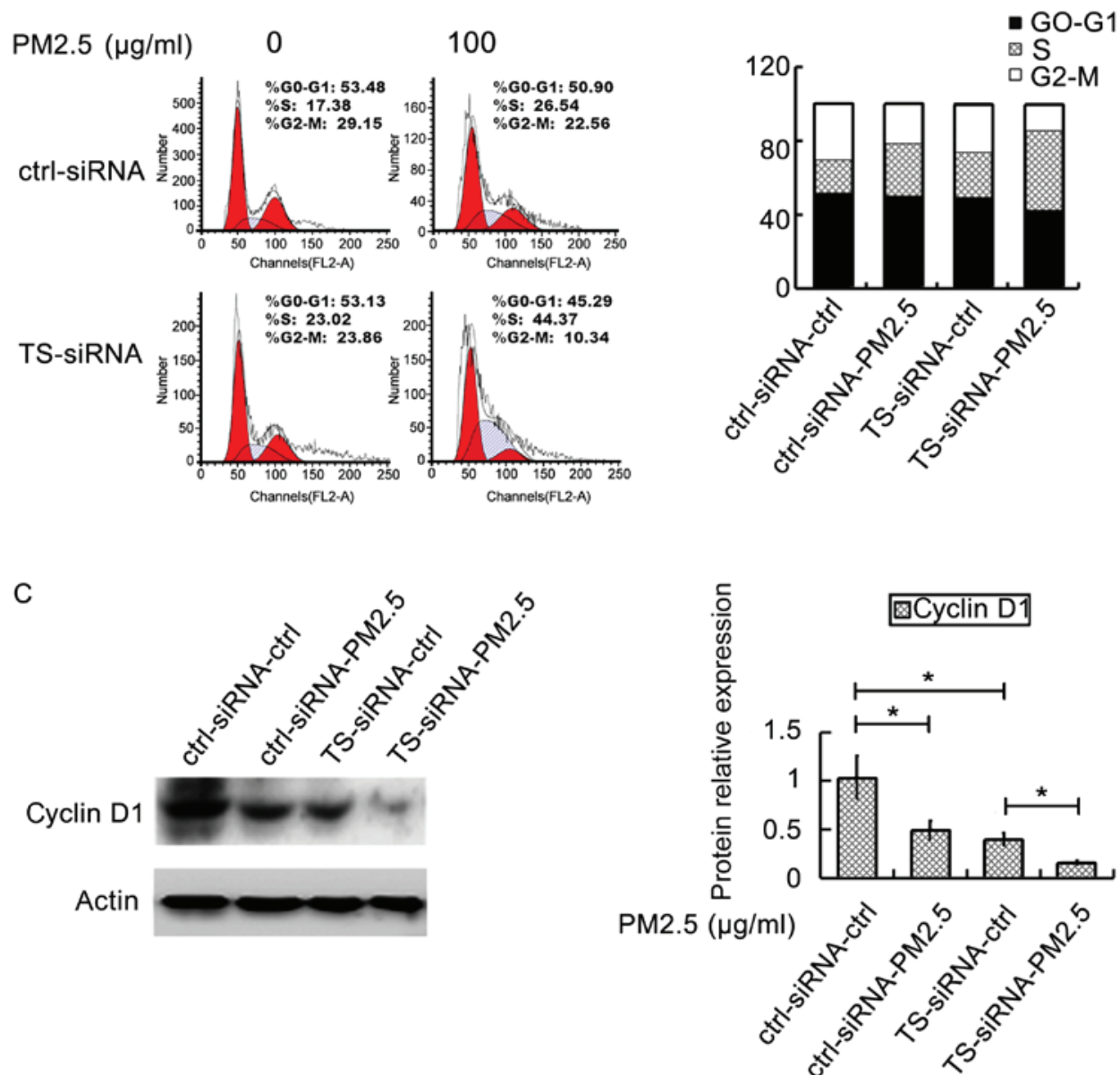

Figure 3. Exposure to PM2.5 induces knockdown of H292 cells by TS protein, which exasperates the cycle arrest. (A) Western blotting of the expression levels of TS protein. TS was inhibited by siRNA. (B) Flow cytometry analysis of $\mathrm{H} 292$ cell cycle. (C) Western blotting of the expression levels of cyclin D1 protein. The final results are summarized in the bar graphs and data are expressed as mean \pm standard deviation $($ " $P<0.05)$. TS, thymidylate synthase.

respectively, compared with the control group (Fig. 2A). The protein expression of TS was downregulated at 4 weeks $(\mathrm{P}<0.05)$ in vivo, and the expression of mRNA of lung tissues was upregulated at 2 weeks $(\mathrm{P}<0.05)$ in $\mathrm{PM} 2.5$-exposed group (Fig. 2B).

Knockout of the TS gene promotes the cell cycle arrest and the downregulation of the expression of cyclin DI protein after PM2.5 exposure. H292 cells were transfected with TS for $48 \mathrm{~h}$ before exposed to PM2.5. Compared with ctrl-siRNA-ctrl (control group), the expression of TS enzyme protein in the ctrl-siRNA-PM2.5 (with PM2.5 exposure), TS-siRNA-ctrl (with TS enzyme inhibitor) and TS-siRNA-PM2.5 (with PM2.5 exposure and TS enzyme inhibitors) groups was downregulated $(\mathrm{P}<0.05)$ (Fig. 3A). The results also showed that the percentage of $S$ phase cells in TS-siRNA groups was higher $(\mathrm{P}<0.05)$ (Fig. 3B). Compared with ctrl-siRNA-ctrl, the expression of cyclin D1 after PM2.5 exposure (ctrl-siRNA-PM2.5), was downregulated $(\mathrm{P}<0.05)$, and the expression of cyclin D1 in TS-siRNA-ctrl group (inhibitor of TS enzyme protein) was downregulated $(\mathrm{P}<0.05)$. Compared with TS-siRNA-ctrl, the expression of cyclin D1 
A

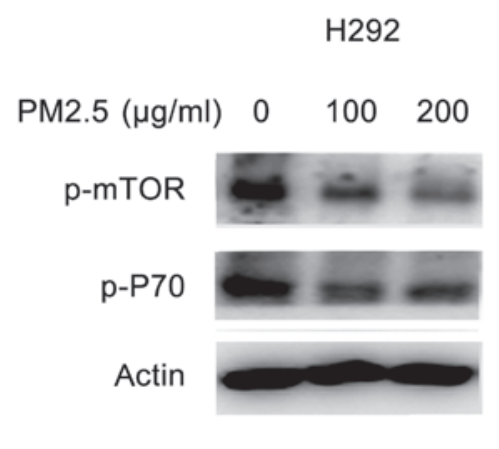

H1299

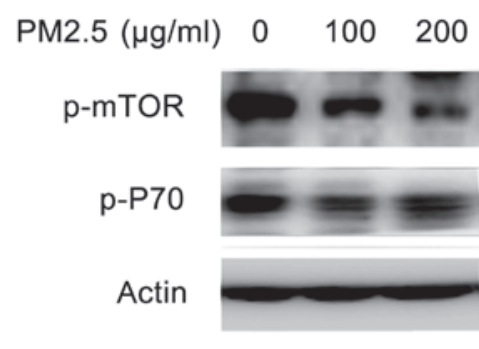

B

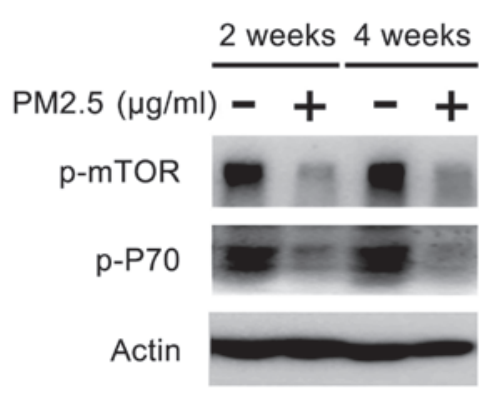

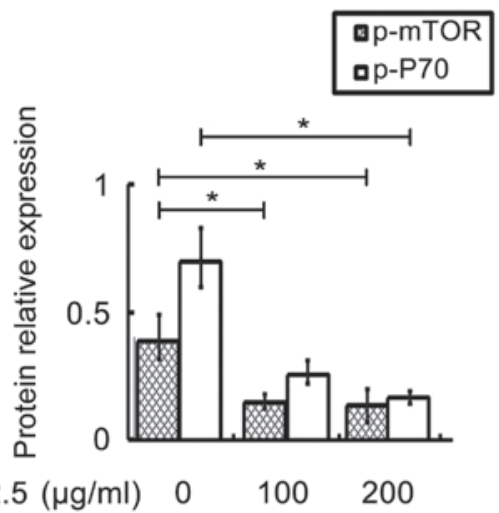

PM2.5 $(\mu \mathrm{g} / \mathrm{ml}) \quad 0 \quad 100 \quad 200$
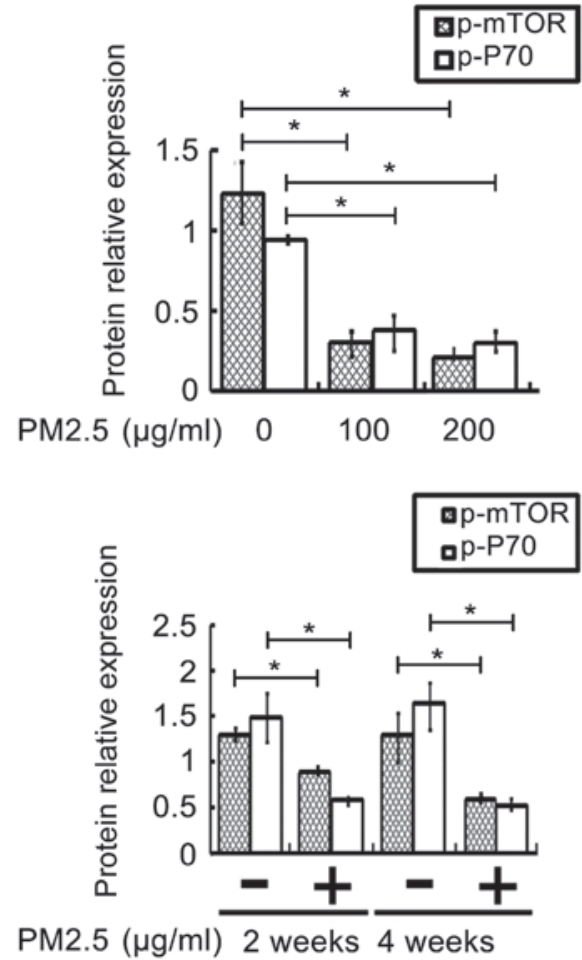

Figure 4. PM2.5 exposure leads to downregulation of mTOR signaling pathway. Western blotting of the expression levels of p-mTOR and p-P70S6K1 proteins in (A) H1299 and H292 cells, and (B) lung tissue. The final results are summarized in the bar graphs and data are expressed as mean \pm standard deviation $\left({ }^{*} \mathrm{P}<0.05\right)$.

protein in the TS-siRNA-PM2.5 group, was downregulated after PM2.5 exposure $(\mathrm{P}<0.05)$ (Fig. 3C).

PM2.5 exposure downregulates the expression of TS and cyclin D1 partially through the downregulation of the mTOR/P70S6K1 signaling pathway. We have found that PM2.5 exposure induced cell cycle arrest in H292 and H1299 cells, and both cyclin D1 and TS proteins were downregulated after PM2.5 exposure. To investigate the downregulation of cyclin D1 and TS enzyme after PM2.5 exposure through the mTOR signaling pathway, we examined the expression of p-mTOR and its downstream molecule p-P70S6K1 in both H292 and H1299 cells. The results showed that the expression levels of $\mathrm{p}-\mathrm{mTOR}$ and p-P70S6K1 were downregulated $(\mathrm{P}<0.05)$ in $\mathrm{H} 1299$ and $\mathrm{H} 292$ cells with increasing PM2.5 concentration at $200 \mu \mathrm{g} /$ $\mathrm{ml}$ (Fig. 4A). In vivo, the expression levels of p-mTOR and p-P70S6K1 were significantly more downregulated $(\mathrm{P}<0.05)$ in the 2- and 4-weeks PM2.5 exposure groups compared with the 2- and 4-weeks control groups (Fig. 4B).

\section{Discussion}

Air pollution is one of the important risk factors affecting public health. In recent years, severe hazy weather appears in many parts of the world, and the occurrence of hazy weather is closely related to the PM2.5 concentration of environmental fine particles. PM2.5 has small particle size, large specific surface area, and presents adsorption of toxic and harmful substances, leading to respiratory and cardiovascular diseases $(22,23)$. In this study, H292 and H1299 cells, as well as and Wistar rats were exposed to PM2.5 suspension to simulate the in vivo and in vitro exposure experiments, respectively, with saline and culture fluid exposure used as control, in order to reduce the experimental error. The results showed that after exposure, the expression of cyclin D1 is downregulated and the cell cycle appears at S phase, in lung tissue and H292 and H1299 cells. Also, this experiment demonstrated that the expression levels of TS enzyme and cyclin D1 proteins are inhibited by PM2.5 due to downregulation of mTOR and P70S6K1 signaling pathway. 
Gualtieri et al have collected airborne particulates during winter and summer in Milan, Italy, and have applied them respectively to A549 cells (24). It was found that PM2.5 collected in winter could induce the production of reactive oxygen species and DNA damage by changing the expression of cellular genes. Billet et al have found that volatile organic compounds and polycyclic aromatic hydrocarbons in PM2.5 play an important role in the toxicity of lung cancer cells (25). Some organic components carried by PM2.5, such as PAH metabolites in human body, can bind covalently to the amino terminal guanine ring of DNA nucleophilic sites to form BPDE-DNA, cause DNA damage, induce gene mutation and carcinogenesis $(26,27)$. Cyclin is the basic process to ensure the cells to carry out life activities. Cyclin D1 is a protein that is closely related to cell growth, development, and tumorigenesis. The cyclin D1 protein plays an important role in regulating the G1/S phase transition of the cell cycle (28). In this experiment, TS enzyme was selected as the research target, and the expression of TS protein was found to be downregulated after exposure to PM2.5, which resulted in the damage of DNA synthesis, thereby affecting the expression of cyclin D1 and the cell cycle arrest.

In this study, we designed interference plasmids for TS genes. After introducing liposome into H292 cells, we found that the expression of TS protein is decreased, suggesting that the expression of TS gene is disturbed by silencing. After knocking down TS, the effects of PM2.5 were enhanced. Also, we found that siRNA targeting silencing of TS gene could result in cell cycle arrest at $\mathrm{S}$ phase in $\mathrm{H} 292$ cells exposed to PM2.5, and the expression of cyclin D1 protein decreases more significantly. The results were statistically significant $(\mathrm{P}<0.05)$.

It has been found that many tumors are associated with an abnormal mTOR signaling pathway in which overexpression of mTOR affects the translational expression of oncogenes such as cyclin D1 (29). The phenomenon of amplification or overexpression of downstream factor P70S6K1 in mTOR also occurs in many tumors. The multiple phosphorylation sites in P70S6K1 are directly regulated by mTOR (30). Phosphorylation is an activated form of the mTOR/P70S6K1 pathway. This study found that exposure of PM2.5 inhibits the activity of mTOR/P70S6K1 signaling pathway leading to downregulated cyclin D1 and TS. PM2.5 occured at least partially through the inhibition of the activity of mTOR/P70S6K1 signaling pathway.

In conclusion, in this study, we systematically studied the toxic effects of PM2.5. The results revealed cell cycle arrest at S phage and showed that cyclin D1 and TS enzyme protein expressions are inhibited by the downregulation of mTOR and P70S6K1 signaling pathway. Knockdown of TS enhances the cell cycle arrest by PM2.5 exposure that inhibits the expression of cyclin D1. TS enzyme may be the target of PM2.5 exposure to regulate cell cycle progression.

\section{Acknowledgements}

The authors wish to thank the following for their support and encouragement: Professor Chunling Xiao, Professor of Shenyang Medical College; Mrs. Dan Yang, Professor Mingyue Ma, Mr. Yang Biao, Miss Guo Jie and Miss Li Bingyu. Thank you to Mr. Aasi's for his support of Afghan foreign students in our College.

\section{Funding}

The study was supported by the Shenyang Medical College Graduate Innovation Fund Project (no. Y20170610), the Liaoning Provincial Department of Science and Technology Project (2017225076), the Shenyang Science and Technology Bureau 'Major Technology R\&D Project' (18-400409), and the Liaoning Province Natural Science Foundation (no. 20170520037).

\section{Availability of data and materials}

The datasets used and/or analyzed during the current study are available from the corresponding author on reasonable request.

\section{Authors' contributions}

YZ and CX assisted with the construction of the animal model. YZ and DY were responsible for the cell culture and PM2.5 treatment, and were involved in the writing of the manuscript. BY and BL performed western blotting. JG contributed to RT-qPCR. All authors read and approved the final manuscript.

\section{Ethics approval and consent to participate}

The study was approved by the Ethics Committee of Shenyang Medical College (Shenyang, China).

\section{Patient consent for publication}

Not applicable.

\section{Competing interests}

The authors declare that they have no competing interests.

\section{References}

1. Zhang YL and Cao F: Fine particulate matter (PM2.5) in China at a city level. Sci Rep 5: 14884, 2015.

2. WHO Regional Office for Europe: Review of evidence on health aspects of air pollution - REVIHAAP Project: Technical Report. WHO Regional Office for Europe, Copenhagen, 2013.

3. Wu S, Deng F, Wei H, Huang J, Wang H, Shima M, Wang X, Qin Y, Zheng C, Hao Y, et al: Chemical constituents of ambient particulate air pollution and biomarkers of inflammation, coagulation and homocysteine in healthy adults: A prospective panel study. Part Fibre Toxicol 9: 49, 2012.

4. Rahman I, Biswas SK and Kode A: Oxidant and antioxidant balance in the airways and airway diseases. Eur J Pharmacol 533: 222-239, 2006.

5. Franklin BA, Brook R and Arden Pope C III: Air pollution and cardiovascular disease. Curr Probl Cardiol 40: 207-238, 2015.

6. Ogino K, Zhang R, Takahashi H, Takemoto K, Kubo M, Murakami I, Wang DH and Fujikura Y: Allergic airway inflammation by nasal inoculation of particulate matter (PM2.5) in NC/Nga mice. PLoS One 9: e92710, 2014.

7. Dai L, Zanobetti A, Koutrakis P and Schwartz JD: Associations of fine particulate matter species with mortality in the United States: A multicity time-series analysis. Environ Health Perspect 122: 837-842, 2014.

8. Fu J, Jiang D, Lin G, Liu K and Wang Q: An ecological analysis of PM2.5 concentrations and lung cancer mortality rates in China. BMJ Open 5: e009452, 2015 
9. Cheng L, Lau WKW, Fung TKH, Lau BWM, Chau BKH, Liang Y, Wang Z, So KF, Wang T, Chan CCH, et al: PM2.5 exposure suppresses dendritic maturation in subgranular zone in aged rats. Neurotox Res 32: 50-57, 2017

10. Duan J, Hu H, Zhang Y, Feng L, Shi Y, Miller MR and Sun Z: Multi-organ toxicity induced by fine particulate matter PM2.5 in zebrafish (Danio rerio) model. Chemosphere 180: 24-32, 2017.

11. Henríquez-Hernández LA, Murias-Rosales A, HernándezGonzález A, Cabrera De León A, Díaz-Chico BN, Mori De Santiago M and Fernández Pérez L: Gene polymorphisms in TYMS, MTHFR, p53 and MDR1 as risk factors for breast cancer: A case-control study. Oncol Rep 22: 1425-1433, 2009.

12. Laplante $M$ and Sabatini DM: mTOR signaling in growth control and disease. Cell 149: 274-293, 2012.

13. Li N, Sui J, Liu H, Zhong M, Zhang M, Wang Y and Hao F: Expression of phosphorylated Akt/mTOR and clinical significance in human ameloblastoma. Int J Clin Exp Med 8: 5236-5244, 2015.

14. Peponi E, Drakos E, Reyes G, Leventaki V, Rassidakis GZ and Medeiros LJ: Activation of mammalian target of rapamycin signaling promotes cell cycle progression and protects cells from apoptosis in mantle cell lymphoma. Am J Pathol 169: 2171-2180, 2006.

15. Wang $X$ and Proud CG: The mTOR pathway in the control of protein synthesis. Physiology (Bethesda) 21: 362-369, 2006.

16. Yang B, Li X, Chen D and Xiao C: Effects of fine air particulates on gene expression in non-small-cell lung cancer. Adv Med Sci 62: 295-301, 2017.

17. Zhao H, Yang B, Xu J, Chen DM and Xiao CL: PM2.5-induced alterations of cell cycle associated gene expression in lung cancer cells and rat lung tissues. Environ Toxicol Pharmacol 52: 77-82, 2017.

18. Xiao C, Li S, Zhou W, Shang D, Zhao S, Zhu X, Chen K and Wang R: The effect of air pollutants on the microecology of the respiratory tract of rats. Environ Toxicol Pharmacol 36: 588-594, 2013.

19. Ma M, Li S, Jin H, Zhang Y, Xu J, Chen D, Kuimin C, Yuan Z and Xiao C: Characteristics and oxidative stress on rats and traffic policemen of ambient fine particulate matter from Shenyang. Sci Total Environ 526: 110-115, 2015.

20. Livak KJ and Schmittgen TD: Analysis of relative gene expression data using real time quantitative PCR and the 2(-Delta Delta C(T)) method. Methods 25: 402-408, 2001.

21. Li R: Transient transfection of CHO cells using linear polyethylenimine is a simple and effective means of producing rainbow trout recombinant IFN- $\gamma$ protein. Cytotechnology 67: 987-993, 2015.
22. Kroll A, Gietl JK, Wiesmüller GA, Günsel A, Wohlleben W, Schnekenburger J and Klemm O: In vitro toxicology of ambient particulate matter: Correlation of cellular effects with particle size and components. Environ Toxicol 28: 76-86, 2013.

23. Samoli E, Stafoggia M, Rodopoulou S, Ostro B, Declercq C, Alessandrini E, Díaz J, Karanasiou A, Kelessis AG, Le Tertre A, et al; MED PARTICLES Study Group: Associations between fine and coarse particles and mortality in Mediterranean cities: Results from the MED-PARTICLES project. Environ Health Perspect 121: 932-938, 2013.

24. Gualtieri M, Longhin E, Mattioli M, Mantecca P, Tinaglia V, Mangano E, Proverbio MC, Bestetti G, Camatini M and Battaglia C: Gene expression profiling of A549 cells exposed to Milan PM2.5. Toxicol Lett 209: 136-145, 2012.

25. Billet S, Garçon G, Dagher Z, Verdin A, Ledoux F, Cazier F, Courcot D, Aboukais A and Shirali P: Ambient particulate matter (PM2.5): Physicochemical characterization and metabolic activation of the organic fraction in human lung epithelial cells (A549). Environ Res 105: 212-223, 2007.

26. Topinka J, Rossner P Jr, Milcova A, Schmuczerova J, Svecova V and Sram RJ: DNA adducts and oxidative DNA damage induced by organic extracts from PM2.5 in an acellular assay. Toxicol Lett 202: 186-192, 2011

27. Vodicka P, Koskinen M, Arand M, Oesch F and Hemminki K: Spectrum of styrene-induced DNA adducts: The relationship to other biomarkers and prospects in human biomonitoring. Mutat Res 511: 239-254, 2002.

28. Shirali S, Aghaei M, Shabani M, Fathi M, Sohrabi M and Moeinifard M: Adenosine induces cell cycle arrest and apoptosis via cyclinD1/Cdk4 and Bcl-2/Bax pathways in human ovarian cancer cell line OVCAR-3. Tumour Biol 34: 1085-1095, 2013.

29. Gera JF, Mellinghoff IK, Shi Y, Rettig MB, Tran C, Hsu JH, Sawyers CL and Lichtenstein AK: AKT activity determines sensitivity to mammalian target of rapamycin (mTOR) inhibitors by regulating cyclin D1 and c-myc expression. J Biol Chem 279: 2737-2746, 2004.

30. Bjornsti MA and Houghton PJ: The TOR pathway: A target for cancer therapy. Nat Rev Cancer 4: 335-348, 2004.

(c) () $\Theta$ This work is licensed under a Creative Commons

Attribution-NonCommercial-NoDerivatives 4.0 International (CC BY-NC-ND 4.0) License. 